\title{
Knowledge Level and Attitude for Human Papillomavirus (HPV) Infection and HPV Vaccines Among Medical School Students
}

\section{Tıp Fakültesi Öğrencilerinin Human Papillomavirüs (HPV) Enfeksiyonu ve HPV Aşıları Hakkında Bilgi Düzeyi ve Tutumları}

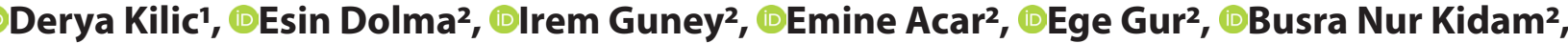 \\ 다olga Guler'
}

'Pamukkale School of Medicine, Department of Obstetrics and Gynecology, Denizli, Turkey

${ }^{2}$ Pamukkale School of Medicine, Denizli, Turkey

\begin{abstract}
Objective: Cervical cancer is a major health issue among women worldwide. Unlike other common cancers, it is almost completely preventable by human papillomavirus (HPV) based screening strategies. The aim of this study was to analyze the knowledge levels of medical students for HPV infection and some of their thoughts regarding HPV vaccine.

Material and Methods: The study was conducted on medical students in the first 3 years of education and their first-degree relatives. The basic data of the questionnaire included 29 multiplechoice questions about the level of knowledge of HPV infection and associated diseases, the level of knowledge of HPV vaccine, and attitude towards HPV vaccine.

Results: Of the study participants, it was found that $158(82.7 \%)$ of the 191 students heard of HPV infection, while 38 (57.6\%) of the 66 student relatives heard of HPV infection, and there was a significant difference between the two groups ( $p \leq 0.005)$. While $120(62.8 \%)$ of the 191 students stated that they heard of HPV vaccine, 30 (45.5\%) of the 66 student relatives stated that they heard of HPV vaccine. Although the level of knowledge of the medical school students was higher compared to their first-degree relatives, there was no significant difference between the two groups in terms of the rates of willingness to get vaccinated.

Conclusion: Education and orientation efforts for both HPV and HPV vaccine should be emphasized more in order to increase the awareness among both university students and society.
\end{abstract}

Keywords: Human papillomavirus, HPV vaccine, students, knowledge

\section{Öz}

Amaç: Serviks kanseri dünya çapında kadınlar arasında önemli bir sağlık sorunudur. Diğer yaygın kanserlerin aksine, insan papilloma virüsü (HPV) tabanlı tarama stratejileri ile neredeyse tamamen önlenebilir. Bu çalışmanın amacı tıp fakültesi öğrencilerinin HPV enfeksiyonu ile ilgili bilgi düzeylerini ve HPV aşısı ile ilgili düşüncelerini analiz etmektir.

Gereç ve Yöntemler: Çalışma, eğitimlerinin ilk 3 yılındaki tıp fakültesi öğrencileri ve birinci derece yakınları üzerinde yürütüldü. Yapılan anketin temel verileri arasında HPV enfeksiyonu ve ilişkili hastalıklar hakkındaki bilgi düzeyi, HPV aşısı hakkındaki bilgi düzeyi ve HPV aşısına karşı tutum hakkında 29 çoktan seçmeli soru bulunmaktaydı.

Bulgular: Çalışmaya katılan 191 öğrenciden 158 (\% 82.7)' inin HPV enfeksiyonunu duyduğu, 66 öğrenci yakınının 38 (\% 57.6)' inin HPV enfeksiyonunu duyduğu ve bu iki grup arasında anlamlı fark bulunduğu saptandı ( $p$ <0.005). 191 öğrenciden 120 (\%62.8)' sinin HPV aşısını duyduğu, 66 öğrenci yakınından ise 30 (\% 45.5)'unun HPV aşısını duydukları saptandı. Tıp fakültesi öğrencilerinin bilgi düzeyi birinci derece yakınlarına göre daha yüksek olmasına rağmen, iki grup arasında aşı olma isteği oranları arasında anlamlı fark saptanmadı.

Sonuç: Hem üniversite öğrencileri arasındaki hem de toplumdaki farkındalığı arttırmak için HPV ve HPV aşısı ile ilgili eğitim ve yönlendirme çabalarına daha fazla önem verilmelidir.

Anahtar Kelimeler: İnsan papilloma virüsü, HPV aşısı, öğrenciler, bilgi düzeyi 


\section{INTRODUCTION}

Cervical cancer is the fourth most common major health issue among women worldwide. Unlike other common cancers, it is one of the few types of cancer that is almost completely preventable. ${ }^{[1]}$ The relationship of human papillomavirus (HPV) with cervical cancer has been well established, and the presence of persistent HPV infection in $99.9 \%$ of patients with cervical cancer has been shown to play a primary role in the etiology. ${ }^{[2,3]}$

The addition of the HPV DNA test to the screening program has significantly increased the sensitivity of the conventional Papsmear test. ${ }^{[4-7]}$ Accordingly, many professional associations including World Health Organization (WHO), European Union and US Preventive Services Task Force (USPSTF) recommend including the HPV infection test in the primary screening program. ${ }^{[8,9]}$ The HPV-based screening program has been implemented in Turkey since 2014 so as to be among the leading countries in the world. According to the new early cancer diagnosis program that has been put into practice, all cases of HPV 16 and HPV 18 infections or all cases of cytological abnormalities with other high-risk HPV infections are referred for colposcopy. ${ }^{[4,5]}$

In addition to the screening program, 3 types of HPV vaccines, including bivalent, quadrivalent and nine-valent, were developed against HPV infection. Although these three vaccines are protective against HPV types 16 and 18, which are responsible for $70 \%$ of cervical cancers, the quadrivalent vaccine has also protective effect against HPV types 6 and 11 and the nine-valent vaccine against HPV types 6, 11, 31, 33, 45, 52 and $58 .{ }^{[10-13]}$ Thus, they also have protective effects against genitoanal warts. Vaccine administration at an early age before exposure to HPV and infection will provide effective protection. HPV vaccination is recommended for all children aged 11 and 12 years, including 9 through 26 years of age, regardless of gender. ${ }^{[12,13]}$

Young adults and university students are at higher risk of genital HPV infection in terms of both risky sexual behaviors, unprotected sex, and HPV-related diseases. ${ }^{[14,15]}$ Among university students, medical students are expected to have the highest level of knowledge of cervical cancer and contribute to the level of awareness in society. The aim of this study was to analyze the knowledge levels of medical students who have not yet started clinical internships and completed their medical education and of their first-degree relatives with whom they are in close contact in the social environment about cervical cancer and HPV vaccine, and some of their thoughts regarding HPV vaccine.

\section{MATERIAL AND METHOD}

The ethical approval for the survey study was obtained from the non-interventional clinical research ethics committee before the study was initiated. The study was conducted on medical students in the first 3 years of education and their first-degree relatives. The study included 257 females who accepted the questionnaire were included in the study between May 2017 and May 2019 at a medical faculty. Of the study participants, 196 were medical students, while 66 were the first-degree relatives of the students.

The questionnaire on cervical cancer screening program, HPV infection, and HPV vaccine was developed using the literature and constituted the data source of the study. The basic data of the questionnaire included 29 multiple-choice questions about the level of knowledge of HPV infection and associated diseases, the level of knowledge of HPV vaccine, and attitude towards HPV vaccine.

All statistical analyses were carried out using the PSPP and $R$ statistical software. The chi-square test and Fisher's exact test were used in the comparisons with categorical variables. Descriptive analysis of the data of the study was conducted by calculating the percentage distributions, central tendency and prevalence measures, maximum and minimum values, and the differences between variables were evaluated using the chi-square, Fisher's exact, Mann-Whitney $U$ and Kruskal Wallis tests. Continuous variables were expressed as mean \pm standard deviation, while categorical variables were expressed as numbers and percentages. A p-value of $<0.05$ was considered statistically significant.

\section{RESULTS}

The questionnaire was administered to a total of 257 individuals within the scope of the study. In general, the mean age of the participants was $25.6( \pm 8.8)$ years. When their educational levels were analyzed, it was found that 210 (81.7\%) individuals were university graduates. In addition, it was determined that of those administered the questionnaire, 151 (58.5\%) had a monthly income above 3000 TL, 106 (41.2\%) had a monthly income below $3000 \mathrm{TL}$, and 52 (20.2\%) of the individuals were regular smokers.

In evaluating the level of knowledge of the participants, only $99(38.5 \%)$ of all participants responded to the question of why smear test is performed as cervical cancer, while $142(55.3 \%)$ stated that they did not have knowledge. When the question of hearing about a virus called HPV is asked, 196 (76.3\%) of the individuals responded positively. Since the next questions were put only to the individuals who stated that they had heard of HPV, the evaluation was carried out with only these 196 individuals. The choices of cervical cancer, ovarian cancer, AIDS and I do not know regarding what diseases the HPV vaccine protects from were marked by $132(67.3 \%), 1$ (0.5\%), 17 (8.7\%) and 46 (23.5\%) participants, respectively. The status of the individuals' willingness to get themselves, their daughters and sons vaccinated against HPV is shown in Table 1.

Table 1. Individuals' willingness to get themselves, their daughters and sons vaccinated against HPV

\begin{tabular}{lll} 
& Willing & Not willing \\
\hline Getting vaccinated for herself & $117(59.7 \%)$ & $79(40.3 \%)$ \\
Getting vaccinated for her daughter & $124(63.3 \%)$ & $72(36.7 \%)$ \\
Getting vaccinated for her son & $87(44.4 \%)$ & $109(45.6 \%)$ \\
\hline
\end{tabular}


The responses to the questions regarding that HPV is sexually transmitted, HPV can cause AIDS, HPV can cause cervical cancer, HPV can cause genital warts, HPV-related diseases can be prevented by vaccination, HPV vaccine is not necessary for individuals who are not sexually active, which were given as true, false or I don't know, are shown in Table 2.

Table 2. Responses to the questions about the level of knowledge of HPV and HPV vaccine

\begin{tabular}{lccc} 
& True & False & $\begin{array}{c}\text { I do not have } \\
\text { any idea/l do } \\
\text { not know }\end{array}$ \\
\hline HPV is sexually transmitted & $141(71.9 \%)$ & $14(7.1 \%)$ & $41(20.9 \%)$ \\
HPV can cause AIDS & $51(26 \%)$ & $71(36.2 \%)$ & $74(37.8 \%)$ \\
HPV can cause cervical cancer & $149(76 \%)$ & $9(4.6 \%)$ & $38(19.4 \%)$ \\
HPV can cause genital warts & $128(65.3 \%)$ & $16(8.2 \%)$ & $52(26.5 \%)$ \\
\hline $\begin{array}{l}\text { HPV-related diseases can be } \\
\text { prevented by vaccination }\end{array}$ & $129(65.8 \%)$ & $11(5.6 \%)$ & $56(28.6 \%)$ \\
\hline $\begin{array}{l}\text { HPV vaccination is not } \\
\begin{array}{l}\text { necessary for those who are } \\
\text { not sexually active }\end{array}\end{array}$ & $11(5.6 \%)$ & $132(67.3 \%)$ & $53(27 \%)$ \\
\hline
\end{tabular}

Of those who participated in the survey study, 191 were medical students, while 66 were the first-degree female relatives of the medical students. When these two sub-groups were analyzed separately, it was found that $158(82.7 \%)$ of the 191 students heard of HPV infection, while 38 (57.6\%) of the 66 student relatives heard of HPV infection, and there was a significant difference between the two groups ( $p \leq 0.005)$. While $120(62.8 \%)$ of the 191 students stated that they heard of HPV vaccine, $30(45.5 \%)$ of the 66 student relatives stated that they heard of HPV vaccine. Among those who heard of HPV infection and HPV vaccine in these groups, the status of the individuals' willingness to get themselves, their daughters and sons vaccinated against HPV is summarized in Table $\mathbf{3}$.

\begin{tabular}{|c|c|c|c|c|}
\hline & & Student & Relative & Total \\
\hline \multirow{2}{*}{$\begin{array}{l}\text { Getting vaccinated } \\
\text { for herself }\end{array}$} & Yes & 98 (62\%) & 19 (50\%) & 117 (59.7\%) \\
\hline & No & 60 (38\%) & 19 (50\%) & 79 (40.3\%) \\
\hline \multirow{2}{*}{$\begin{array}{l}\text { Getting vaccinated } \\
\text { for her daughter }\end{array}$} & Yes & $106(67.1 \%)$ & 18 (47.4\%) & 124 (63.3\%) \\
\hline & No & $52(32.9 \%)$ & 20 (52.6\%) & 72 (36.7\%) \\
\hline \multirow{2}{*}{$\begin{array}{l}\text { Getting vaccinated } \\
\text { for her son }\end{array}$} & Yes & 76 (48.1\%) & 11 (28.9\%) & 87 (44.4\%) \\
\hline & No & 82 (51.9\%) & 27 (71.1\%) & 109 (55.6\%) \\
\hline
\end{tabular}

Although the level of knowledge of the medical school students was higher compared to their first-degree relatives, there was no significant difference between the two groups in terms of the rates of willingness to get vaccinated. When the reason for not willing to get vaccinated was questioned, of the individuals, $162(82.7 \%)$ stated that they did not want to get vaccinated because of insufficient knowledge, $8(4.1 \%)$ because of side effect concern, 7 (3.6\%) because of the price, $1(0.5 \%)$ because of fear of vaccination, $12(6.1 \%)$ because of finding it unnecessary, and 6 (3.1\%) reported that they did not want to get vaccinated for other reasons.
Table 4. Responses of medical students and their relatives to the level of knowledge questions about HPV and HPV vaccine

\begin{tabular}{|c|c|c|c|c|}
\hline & & True & False & $\begin{array}{l}\text { I do not } \\
\text { have any } \\
\text { idea/l do } \\
\text { not know }\end{array}$ \\
\hline \multirow{2}{*}{$\begin{array}{l}\text { HPV is sexually } \\
\text { transmitted }\end{array}$} & Student & 125 (65.4\%) & 7 (3.7\%) & 59 (30.9\%) \\
\hline & Relative & $28(42.4 \%)$ & 7 (\%10.6) & 31 (47.0\%) \\
\hline \multirow{2}{*}{$\begin{array}{l}\text { HPV can cause } \\
\text { AIDS }\end{array}$} & Student & 40 (20.9\%) & 64 (33.5\%) & 87 (45.5\%) \\
\hline & Relative & $17(25.8 \%)$ & $10(15.2 \%)$ & 39 (59.1\%) \\
\hline \multirow{2}{*}{$\begin{array}{l}\text { HPV can cause } \\
\text { cervical cancer }\end{array}$} & Student & $128(67 \%)$ & $8(4.2 \%)$ & 55 (28.8\%) \\
\hline & Relative & $32(48.5 \%)$ & $2(3 \%)$ & 32 (48.5\%) \\
\hline \multirow{2}{*}{$\begin{array}{l}\text { HPV can cause } \\
\text { genital warts }\end{array}$} & Student & $110(57.6 \%)$ & 17 (8.9\%) & $64(33.5 \%)$ \\
\hline & Relative & 26 (39.4\%) & 1 (1.5\%) & 39 (59.1\%) \\
\hline \multirow{2}{*}{$\begin{array}{l}\text { HPV-related } \\
\text { diseases can be } \\
\text { prevented by } \\
\text { vaccination }\end{array}$} & Student & 112 (58.6\%) & 12 (6.3\%) & 67 (35.1\%) \\
\hline & Relative & $29(43.9 \%)$ & $0(0 \%)$ & 37 (56.1\%) \\
\hline \multirow{2}{*}{$\begin{array}{l}\text { HPV vaccination is } \\
\text { not necessary for } \\
\text { those who are not } \\
\text { sexually active }\end{array}$} & Student & 7 (3.7\%) & 120 (62.8\%) & 64 (33.5\%) \\
\hline & Relative & 7 (\%10.6) & 21 (31.8\%) & 38 (57.6\%) \\
\hline
\end{tabular}

\section{DISCUSSION}

Although 196 participants heard of HPV in our study, 40.3\% of these patients did not want to get vaccinated. It was found that of the participants, $36.7 \%$ did not want to get their daughters vaccinated and $45.5 \%$ did not want to get their sons vaccinated. In addition, only $71.9 \%$ of the participants knew that HPV was a sexually transmitted disease. Interestingly, only $36.2 \%$ of the participants stated that HPV was not associated with AIDS. On the other hand, it was observed that $76 \%$ of the participants knew that HPV was associated with cervical cancer, while only $65.8 \%$ of the participants knew that HPV virus could be prevented by vaccination.

Unfortunately, the level of knowledge of HPV and HPV vaccine is quite low, especially in developing countries. ${ }^{[16,17]}$ In a 2009 study conducted in Turkey, Onan et al. reported that $24.8 \%$ of women heard of HPV infection and $24.3 \%$ of them heard of HPV vaccine. ${ }^{[18]}$ Likewise, a survey study conducted on 525 Turkish women on similar dates reported that $56 \%$ of women never heard of HPV infection. ${ }^{[19]}$ However, since then, the cervical cancer screening program has changed in our country and the HPV-based screening system has been put into practice. In our study, it is still seen that the level of knowledge of both HPV infection and HPV vaccine is not at the desired level. When we analyzed the students and their relatives separately, only $62 \%$ of the students whose level of knowledge was expected to be higher, stated that they would like to get vaccinated, while $50 \%$ of their relatives did not want to get vaccinated. In fact, the results of the survey revealed that the level of knowledge of HPV was higher in the students, but no significant difference was found between the two groups when it comes to vaccination. In our study, $65.8 \%$ of the students stated that they wanted to get their daughters vaccinated, while $48.1 \%$ of them stated that they wanted to get their sons vaccinated. Of the student relatives, $47.4 \%$ stated they wanted to get their daughters vaccinated, while $28.9 \%$ stated that they wanted to get their sons vaccinated. 
Unlike our study, Cesmeci et al. ${ }^{[20]}$ evaluated the knowledge, opinions, and behaviors of the senior medical students towards HPV infection and vaccine in their study. When the level of knowledge of the participants was analyzed in that study, the most known issue was that HPV was the cause of cervical cancer in most cases. However, a significant difference was found between the economic status of the participants and their status of not getting vaccinated and not recommending HPV vaccine to their male patients and gender. As a result, although the level of the participants was high, the percentage of getting vaccinated was found to be quite low. Several studies have reported that the awareness of HPV infection among university students is not high, although it varies on the basis of race, gender, and country. ${ }^{[15,21-23]}$ However, because of their sexual behaviors, university students also constitute a high-risk group in terms of HPV infection. ${ }^{[24,25]}$ In our study, it is interesting data that only $65.4 \%$ of the students knew that HPV was a sexually transmitted disease and only $33.5 \%$ of the students stated that they knew that HPV was not a virus associated with AIDS. Based on this, it can be concluded that even medical students confuse HPV with HIV. Of the students, $67 \%$ knew that HPV was associated with cervical cancer. While only $58.6 \%$ of the students knew that HPV virus could be prevented by vaccination. The rate of willingness to get vaccinated was $62 \%$, which is a relatively low rate, even considering the students who knew that HPV virus could be prevented by vaccination.

When the reason for not wanting to get vaccinated was questioned, it was found that the vast majority did not want to get vaccinated due to insufficient knowledge. Obviously, this suggests that prejudice against the vaccine may have developed due to lack of knowledge. The results show that both university students and their relatives have a lack of knowledge, especially about that males can be vaccinated. In addition, this suggests that sufficient awareness of the requirement to get their sons vaccinated could not have been created in the participants who knew that HPV was associated with cervical cancer (76\%). In the study by Cesmeci et al., the high cost of vaccination, the fact that the participants did not prefer to get vaccinated against HPV because they were male and that the participants did not find HPV vaccine necessary in general were the main reasons why participants did not prefer to get vaccinated against HPV. ${ }^{[20]}$ Similarly, other studies conducted on girls and their families in different regions were about what HPV is, how HPV is transmitted, and the association between HPV and cervical cancer. It has been reported that there is a lack of knowledge about HPV vaccine, what the vaccine protects against, how the vaccine works, the recommendations about HPV vaccine, the link between the vaccine and Pap smear, and the legends about HPV vaccine. [26,27]

Some of the most important limitations of our study are the sample size and not being able to reach the firstdegree relatives of all students. At the same time, another limitation to consider when interpreting this study is that the information obtained was collected using a self-administered questionnaire and therefore some participants may have provided false information.

\section{CONCLUSION}

Although the high compliance to HPV based cancer screening program in Turkey, knowledge level and attitude of HPV infection and HPV vaccines are low even in medical students. In the light of these results, education and orientation efforts for both HPV and HPV vaccine should be emphasized more in order to increase the awareness among both university students and society. Increasing the level of knowledge and correcting incomplete and incorrect knowledge should be a part of the cervical cancer prevention program.

\section{ETHICAL DECLARATIONS}

Ethics Committee Approval: This study was approved by Pamukkale University Ethics Committee (Referans Number: 60116787-020/90570).

Informed Consent: Because the study was designed retrospectively, no written informed consent form was obtained from patients.Referee Evaluation Process: Externally peer-reviewed.

Conflict of Interest Statement: The authors have no conflicts of interest to declare.

Financial Disclosure: The authors declared that this study has received no financial support.

Author Contributions: All of the authors declare that they have all participated in the design, execution, and analysis of the paper, and that they have approved the final version.

\section{REFERENCES}

1. Bray F, Ferlay J, Soerjomataram I, Siegel RL, Torre LA, Jemal A. Global cancer statistics 2018: GLOBOCAN estimates of incidence and mortality worldwide for 36 cancers in 185 countries. CA Cancer J Clin. 2018;68(6):394-424.

2. Walboomers JM, Jacobs MV, Manos M, et al. Human papillomavirus is a necessary cause of invasive cervical cancer worldwide. J Pathol 1999;189:12-9.

3. Ramael M, Gudleviciene Z, Didziapetriene J. Natural history and biological behaviour of human papillomavirus: implications for cervical cancer screening. ACTA Med Lituanica 2004;11:1-7.

4. Gultekin M, Zayifoglu Karaca M, Kucukyildiz I, et al. Initial results of population based cervical cancer screening program using HPV testing in one million Turkish women. Int J Cancer. 2018;142(9):1952-8.

5. TC Sağlık Bakanlığı Halk Sağlığı Genel Müdürlüğü Kanser Dairesi Başkanlığı. Aviable online: 2020: https://hsgm.saglik.gov.tr/tr/kanser-taramastandartlari/listesi/483-serviks-kanseri-tarama-program\%C4\%B1-ulusalstandartlar\%C4\%B1.html

6. Ronco G, Dillner J, Elfstr€om KM, et al. Efficacy of HPV-based screening for prevention of invasive cervical cancer: follow-up of four European randomised controlled trials. Lancet 2014;383:524-32

7. Gage JC, Schiffman M, Katki HA, et al. Reassurance against future risk of precancer and cancer conferred by a negative human papillomavirus test. J Natl Cancer Inst 2014;106. 
8. US Preventive Services Task Force. Screening for cervical cancer US Preventive Services Task Force recommendation statement. JAMA 2018;320: 674-86.

9. WHO, Human Papillomavirus (HPV) and Cervical Cancer, 2018. https:// www.who.int/immunization/diseases/hpv/en/

10. Joura $E A$, Giuliano $A R$, Iversen $O E$, et al. A 9-valent $H P V$ vaccine against infection and intraepithelial neoplasia in women. N Engl J Med. 2015;372(8):711-23.

11. Human papillomavirus vaccination. Committee Opinion No. 704. American College of Obstetricians and Gynecologists. Obstet Gynecol 2017;129:e173-8.

12. Harper DM, DeMars LR. HPV vaccines - a review of the first decade. Gynecol Oncol 2017;146:196-204.

13. Kim KS, Park SA, Ko KN, Yi S, Cho YJ. Current status of human papilloma virus vaccines. Clin Exp Vaccine Res. 2014;3:168-75.

14. Vail-Smith K, White DM. Risk level, knowledge, and preventive behavior for human papillomaviruses among sexually active college women. J Am Coll Health 1992;40:227-30.

15. Sandfort JR, Pleasant A. Knowledge, attitudes, and informational behaviors of college students in regard to the human papillomavirus. J Am Coll Health 2009;58:141-9.

16. Cuzick J, Arbyn M, Sankaranarayanan R, et al. Overview of human papillomavirus-based and other novel options for cervical cancer screening in developed and developing countries. Vaccine 2008;26:29-41.

17. Alsaad MA, Shamsuddin K, Fadzil F. Knowledge towards HPV infection and HPV vaccines among Syrian mothers. Asian Pac J Cancer Prev. 2012;13(3):879-83.

18. Onan A, Ozkan S, Korucuoglu $U$, et al. Knowledge on and attitude towards human papillomavirus infection and its vaccine in a Turkish subpopulation. Turkiye Klinikleri J 2009;29:594-8.

19. Ilter E, Celik A, Haliloglu B, et al. Women's knowledge of Pap smear test and human papillomavirus: acceptance of HPV vaccination to themselves and their daughters in an Islamic society. Int J Gynecol Cancer 2009; 20:1058-62.

20. Çeşmeci Y, Koylu B, SulaimaN J, et al. HPV infection and hpv vaccine through the eyes of interns. Turk Jinekolojik Onkoloji Derg. 2015;3:85-92.

21. Gerend MA, Shepherd JE. Correlates of HPV knowledge in the era of HPV vaccination: a study of unvaccinated young adult women. Women Health. 2011;51(1):25-40.

22. Makwe CC, Anorlu Rl, Odeyemi KA. Human papillomavirus (HPV) infection and vaccines: knowledge, attitude and perception among female students at the University of Lagos, Lagos, Nigeria. J Epidemiol Glob Health. 2012 Dec;2(4):199-206.

23. Cooper DL, Zellner-Lawrence T, Mubasher M, Banerjee A, Hernandez ND. Examining HPV Awareness, Sexual Behavior, and Intent to Receive the HPV Vaccine Among Racial/Ethnic Male College Students 18-27 years. Am J Mens Health. 2018;12(6):1966-75.

24. Makwe CC, Anorlu RI, Odeyemi KA. Human papillomavirus (HPV) infection and vaccines: knowledge, attitude and perception among female students at the University of Lagos, Lagos, Nigeria. J Epidemiol Glob Health. 2012 Dec;2(4):199-206.

25. Panatto D, Amicizia D, Trucchi C, et al. Sexual behaviour and risk factors for the acquisition of human papillomavirus infections in young people in Italy: suggestions for future vaccination policies. BMC Public Health. 2012;12:623.

26. Yu Y, Xu M, Sun J, et al. Human Papillomavirus Infection and Vaccination: Awareness and Knowledge of HPV and Acceptability of HPV Vaccine among Mothers of Teenage Daughters in Weihai, Shandong, China. PLoS One. 2016;11(1):e0146741.

27. Grandahl M, Paek SC, Grisurapong S, Sherer $P$, Tydén T, Lundberg P. Parents' knowledge, beliefs, and acceptance of the HPV vaccination in relation to their socio-demographics and religious beliefs: A crosssectional study in Thailand [published correction appears in PLoS One 2018;19:13(4):e0196437. 